\title{
Expression of the epithelial polymeric immunoglobulin receptor is decreased in allergic rhinitis and eosinophilic rhinosinusitis
}

\author{
Cloé Hupin ${ }^{1 *}$, Philippe Rombaux ${ }^{1}$, Marylène Lecocq ${ }^{2}$, Charles Pilette ${ }^{2}$ \\ From 9th Symposium of Experimental Rhinology and Immunology of the Nose (SERIN 2013) \\ Leuven, Belgium. 21-23 March 2013
}

\section{Background}

Transcytosis of immunoglobulin A (IgA) through polarized bronchial and sinonasal epithelial cells is mediated by the polymeric immunoglobulin receptor (pIgR), which represents the rate-limiting factor for this frontline protective mechanism in the airways. pIgR expression is decreased in COPD, lung cancer and nasopharyngeal carcinoma, while its role in sinonasal chronic inflammatory diseases has not been explored. The aim of this study was thus to assess pIgR expression in sinonasal mucosa of patient with chronic rhinosinusitis with (CRSwNP) or without polyps (CRSsNP) and in allergic rhinitis (AR), as well as IgA and SC (the released soluble part of the pIgR) in nasal secretions.

\section{Methods}

Nasal and ethmoidal biopsies, as well as nasal fluid, were collected from patients with CRSwNP, CRSsNP and AR, as compared to control subjects. pIgR expression was analyzed by RT-qPCR and immunohistochemistry. IgA and $\mathrm{SC}$ were measured in nasal secretions by ELISA. Quantification of mucosal eosinophils was performed following hematoxylin-eosin staining.

\section{Results}

RT-qPCR showed a significant reduction of pIgR expression in ethmoidal biopsies from CRSwNP $(\mathrm{p}=0,01)$ and AR $(p=0,04)$. This reduction was confirmed at the protein level by immunohistochemistry, and resulted into reduced levels of SC and trends for reduced IgA in nasal secretions from these patients. Decreased pIgR expression

${ }^{1}$ Cliniques Universitaires Saint-Luc, Service d'Oto-Rhino-Laryngologie, Brussels, Belgium

Full list of author information is available at the end of the article was mainly observed in patients with increased mucosal eosinophils.

\section{Conclusion}

Epithelial pIgR expression is decreased in patients with CRSwNP and AR, results in decreased SC (and IgA) in nasal secretions, and closely relates to Th2-type eosinophilic inflammation. Whether this defect leads to impaired defense of the upper airways against pathogens remains to explore.

\section{Author details}

${ }^{1}$ Cliniques Universitaires Saint-Luc, Service d'Oto-Rhino-Laryngologie, Brussels, Belgium. ${ }^{2}$ Université Catholique de Louvain, IREC, Pole de Pneumologie, ORL \& Dermatologie, Brussels, Belgium.

Published: 16 July 2013

\section{doi:10.1186/2045-7022-3-S2-08}

Cite this article as: Hupin et al: Expression of the epithelial polymeric immunoglobulin receptor is decreased in allergic rhinitis and eosinophilic rhinosinusitis. Clinical and Translational Allergy 2013 3(Suppl 2):08.

Submit your next manuscript to BioMed Central and take full advantage of:

- Convenient online submission

- Thorough peer review

- No space constraints or color figure charges

- Immediate publication on acceptance

- Inclusion in PubMed, CAS, Scopus and Google Scholar

- Research which is freely available for redistribution

\section{Biomed Central}

